Гарнага О. М. [1; ORCID ID: 0000-0002-5236-7299], к.е.н., доцент

${ }^{1}$ Національний університет водного господарства та природокористування, м. Рівне

\title{
АНАЛІЗ I ПРОГНОЗУВАННЯ В СИСТЕМІ МІЖНАРОДНИХ ЕКОНОМІЧНИХ ВІДНОСИН
}

У статті розглянуто методологічні аспекти аналізу та прогнозування в системі міжнародних економічних відносин. Зазначено, що чим вищий і детальніший рівень розробки прогнозів та їх якість, чим достовірнішими та ефективнішими вони $€$, тим результативнішим є планування та управління міжнародним економічним розвитком суспільства. Проаналізовано методи контент-аналізу та івент-аналізу.

Ключові слова: аналіз; прогнозування; міжнародні відносини; планування; зовнішньополітичне прогнозування.

Вступ. Міжнародні економічні відносини країн світу не можуть ефективно розвиватися без їх аналізу та розробки якісних прогнозів. Чим вищий та детальніший рівень розроблення прогнозів та їх якість, чим реалістичнішими та ефективнішими вони $\epsilon$, тим результативнішим $€$ планування та управління міжнародним економічним розвитком суспільства. Складність процедури аналізу та прогнозування полягає у тому, що, з одного боку, розробка прогнозу знаходиться у площині різновекторних дисциплін, таких як міжнародна економіка, статистика, історія, соціологія, психологія, філософія тощо. 3 іншого - аналіз та прогнозування міжнародних економічних відносин загалом $€$ невід'ємною складовою управління та значно залежить від нормативно-правової бази держави, ступеня розвитку політичних та неполітичних інститутів. Оскільки не лише одержаний прогноз, а й шлях його отримання має бути обґрунтованим, істинним та раціональним. Детальне вивчення методологічних аспектів аналізу та прогнозування міжнародних економічних відносин $€$ особливо актуальною та важливою темою сьогодення.

Аналіз останніх досліджень і публікацій. Дослідження аналітичних та прогнозних аспектів у системі міжнародних економічних відносин перебувають у центрі уваги зарубіжних та українських науковців, зокрема А. Ахременко, Д.Лук'яненка, С. Боринця, С. Сьоміна, О. Титаренко, С. Телешуна та інших учених. 
Проте, звісно, що багато питань лишаються ще не до кінця дослідженими і потребують поглибленої розробки теоретичних i методологічних аспектів щодо вивчення аналізу і прогнозування в системі міжнародних економічних відносин.

Постановка завдання. Мета статті полягає в дослідженні аналізу і прогнозування в системі міжнародних економічних відносин.

Викладення основного матеріалу. Однією з фундаментальних функцій управління $\epsilon$ функція прогнозування, що походить безпосередньо з самої суті категорії управління, оскільки воно повинно вирішувати як поточні завдання, так і проблеми в перспективі. В цілому під прогнозом в науці мають на увазі ймовірне, науково обгрунтоване судження про майбутнє [1, С. 23]. Саме імовірнісна суть прогнозу та його наукова обґрунтованість вирізняє даний вид знання від інших різних форм передбачення. Процес розроблення прогнозів називають прогнозуванням. У контексті управління прогнозування - це певне наукове передбачення, процес систематичного дослідження стану, структури, динаміки та можливих перспектив управлінських явищ та процесів, які притаманні об'єкту та суб'єкту управління. Значною мірою прогнозування зумовлено також характером об'єкта управління, який, як правило, $є$ динамічним. Враховуючи, що не $є$ можливим здійснювати результативні управлінські дії без знання їх наслідків, вся управлінська система повинна бути прогнозованою. Отже, в процесі управління прогнозування використовується як функція, принцип та метод самого управління. Варто зазначити, що прогнозування як функція тісно пов'язана 3 іншою функцією плануванням, яке завжди присутнє на всіх щаблях ієрархії управління. Сама ця функція окреслює цілі, завдання, напрями та способи реалізації соціально-економічних і політичних процесів, без неї неможливе нормальне функціонування міжнародної економічної системи. Роль прогнозування при цьому важко переоцінити, оскільки воно сприяє ефективнішим розробкам міжнародних програм, допомагає прораховувати різні варіанти розвитку можливих ситуації після прийняття тих чи інших державних рішень. Як правило, класифікація прогнозів відбувається за об'єктом дослідження. Відповідно вирізняють природничі, науково-технічні, соціальні та політичні прогнози. Сферою наймасовіших наукових досліджень $€$ міжнародні соціально-економічні прогнози. Під категорією «соціальне прогнозування» мають на увазі дослідження перспектив розвитку різноманітних соціальних процесів і явищ, мета якого підвищення наукової обґрунтованості та ефективності соціального 
програмування, планування та управління [2, С. 171].

Важливою ціллю міжнародного соціального прогнозування $\epsilon$ підготовка науково обґрунтованих пропозицій стосовно того, в якому напрямі $€$ бажаним розвиток визначеного соціального об'єкта [3]. У свою чергу, політичний прогноз - це науково обґрунтоване, імовірне судження стосовно можливих станів політичних систем, процесів, суб'єктів у майбутньому, тенденцій їх розвитку [1, С. 23]. Соціальноекономічне та політичне та прогнозування на міжнародній арені дуже тісно пов'язані між собою, тому що соціальна система пов'язана 3 політичною системою, більше того, iї розвиток та структура залежать від процесів модернізації або трансформації політичної системи. Отож, розроблення ефективних та адекватних міжнародних соціальних прогнозів неможливе без такої ж роботи в міжнародній політичній сфері і навпаки.

Соціально-економічні прогнози поділяють на кілька напрямів, серед яких особливий інтерес становлять зовнішньополітичні та внутрішньополітичні. Внутрішньополітичне прогнозування - це сфера взаємовідносин між націями, класами та іншими соціальними групами. Варто вирізняти два аспекти в сфері прогнозування внутрішньої політики. Перший пов'язаний з прогнозними оцінками окремих політичних дій, другий аспект охоплює діяльність політичних інститутів суспільства та політичних процесів, що мають місце зараз. Зовнішньополітичне прогнозування - це прогнози в сфері зовнішньої політики та міжнародних відносин. Усі види прогнозів завжди пов'язані між собою, це зрозуміло, адже існує зв'язок між різного виду прогнозами. Для кожного прогнозу варто обробляти більше інформації за спорідненими напрямами. Рівень достовірності прогнозу є прямо пропорційним обсягу використаних матеріалів. Щоб розробити прогноз, слід визначити головні та допоміжні напрями робіт [2]. Соціально-політичне прогнозування вважають частиною системи міжнародного державного прогнозування, під яким розуміють систему науково-обґрунтованих досліджень та різних науково-практичних заходів кількісного та якісного характеру, які проводять органи державної влади з метою окреслення перспектив розвитку держави або основних напрямів державного управління в соціальній, політичній, економічній та інших сферах. Фундаментальним завданням прогнозування на міжнародному рівні $€$ пошук оптимальних шляхів розвитку всіх сфер життєдіяльності суспільства. Відповідно воно має застосунок переважно на стадії розробки планів, програм у певній сфері та сприяє виробленню концепцій, рекомендацій та пропозицій з їх 
реалізації, суттєвий вплив чинить на підготовку та прийняття управлінських рішень. У закордонних державах результати прогнозування, згідно 3 їх законодавством, повинні використовуватися при прийнятті органами законодавчої та виконавчої влади визначених рішень у галузі соціально-економічної політики - на короткострокову, середньострокову та довгострокову перспективу. При цьому мова йде про розроблення державних прогнозів у декількох варіантах з врахуванням імовірнісного впливу зовнішніх та внутрішніх факторів тощо.

Водночас слід зазначити, що, на відміну від інших сфер, у соціально-політичній сфері від самого початку можливості для здійснення прогнозування значно менші. Причиною $€$ відносно слабші вихідні інформаційні масиви, які необхідні для побудови динамічних схем. Також рівень математизації досліджень є доволі невисоким, що суттєво звужує можливості для застосування методів моделювання. Не варто забувати, що дуже складними є самі по собі явища, що прогнозуються, відповідно йдеться передусім про короткотермінові прогнози, що базуються на приблизних оцінках. Такими прогнозами може займатися невелика кількість експертів, які мають відповідну фахову підготовку, або ж спеціалізовані установи, яких дуже мало [4].

Дискусійною лишається проблематика вибору методів прогнозування у системі міжнародних відносин. Так, певна частина дослідників до них відносять експертні методи, методи екстраполяції, моделювання. Інша група науковців розділяє методи прогнозування на загальнонаукові та частково наукові. Найкращим, ми вважаємо, є виділення загальнонаукової групи методів прогнозування, що складається з екстраполяції, аналізу і синтезу, інтерполяції, індукції, дедукції, аналогії, гіпотези, експериментування [3, С. 331]. До інноваційних методів, в основі яких лежить колективна думка, належать методи «мозкової атаки», експертні опитування, тестування, а також метод «Дельфі». Стосовно соціальноекономічного проєктування, то воно меншою мірою детермінує інші функції управління, оскільки допускає можливість багатоваріантних рішень, виходячи з наявних трудових, матеріальних та фінансових ресурсів. При цьому воно може не володіти інформацією щодо конкретних термінів реалізації проєктів. У цілому міжнародне соціально-економічне проєктування - це специфічна діяльність, тісно пов'язана 3 науково обґрунтованим визначенням варіантів розвитку нових соціальних процесів та явищ, з подальшою зміною конкретно визначених соціальних інститутів. Ключовим чинником результативного соціально-економічного прогнозування на 
міжнародній арені $€$ наявність високопрофесійних спеціалістів та закладів, здатних розробити і представити прогнози.

Стосовно сучасного стану соціально-економічного прогнозування в міжнародній системі відносин в українському суспільстві, то він наразі лишається незадовільним. По-перше, відсутня інтелектуальна конкуренція серед політичної та управлінської еліт, що призводить до частих криз у суспільстві, які пов'язані як із відсутністю відповідальності владних структур перед суспільством, так і з небажанням бізнесу використовувати політичний аналіз та прогнозування у своїй діяльності. По-друге, слід враховувати також такий факт, що спеціалісти, які претендують на право надавати соціально-політичні прогнози, не повною мірою оперують мінімально необхідним теоретичним та практичним інструментарієм [2, С. 169]. По-третє, відділи прогнозного супроводу органів держвлади та місцевого самоврядування діють переважно в інтересах управлінь внутрішньої політики і працюють виключно в сфері збирання та фахової обробки інформації. Недостатнім $\epsilon$ методологічне забезпечення діяльності цих структурних підрозділів. По-четверте, в органах держвлади існує проблема у відносинах «клієнт-замовник», оскільки чітко визначена ієрархічна структура органів державної влади та місцевого самоврядування створює ймовірність для нав'язування аналітично-прогностичним підрозділам волі вищого керівництва щодо результатів проведених досліджень та моніторингів.

При такому розвитку подій вести мову про об'єктивність досліджень, а відтак про їх фаховість та значимість, не приходиться. По-п'яте, існує проблема недосконалості нормативно-правової бази діяльності системи інформаційно-аналітичного та прогностичного забезпечення органів держвлади і місцевого самоврядування в нашій країні, що пов'язано з відставанням засобів законодавчого регулювання від сучасних політичних, соціально-економічних реалій.

Варто наголосити на недостатньому рівні фінансування системи соціально-економічного прогнозування. На відміну від країн ЄС та США, робота українських аналітиків у сфері соціально-політичного прогнозування $€$ низькооплачуваною.

Тому для удосконалення впровадження соціально-політичних прогностичних розвідок в сучасну управлінську практику (як на державному рівні, так і на рівні організацій), на наше переконання, органам державної влади спільно з науково-дослідними закладами, вищими навчальними установами передусім варто підготувати 
технічні завдання з розбудови інформаційно-аналітичних систем та ïх прогностичних елементів за визначеними напрямами функціонування органів державної влади. Також правильним $\epsilon$ запровадження дієвих механізмів співпраці між державними та не державними інформаційно-аналітичними структурами в сфері розроблення коротко-, середньо- та довготермінових прогнозів (зокрема через здійснення спільних досліджень з актуальних питань зовнішньої та внутрішньої політики). Не менш значущим є посилення співпраці прогностичних структур органів державної влади та місцевого самоврядування 3 вітчизняним науково-академічним середовищем (це дасть можливість значно оптимізувати та зробити більш дієвим обмін науково-методологічними доробками, покращити підготовку та перепідготовку спеціалістів з прогностичної роботи через стажування, проведення тренінгів для студентів 3В0, що демонструють бажання і мають схильність до прогностичної діяльності. Вважаємо, що у даному аспекті провідна роль повинна належати Національній академії державного управління при Президентові України та їі регіональним філіям. Нарешті, слід обмежити практику підготовки проєктів та програм прогностичними органами державної влади та місцевого самоврядування «під себе» (виходячи лише з політичної доцільності та власного місця у владній ієрархіі). Реалізація вищезазначеного пакету пропозицій дасть можливість суттєво оптимізувати процес розроблення соціальноекономічних прогнозів в країні, ефективно використовувати одержані дані при плануванні різних реформ тощо.

Досліджуючи вибір окремих дослідницьких прийомів при аналізі міжнародних відносин, то слід наголосити, що він визначається особливостями поставлених завдань, тому маючи на меті дослідження підготовки сприйняття суспільством владного рішення на політичній арені, звернемо увагу на такі методи, як аналіз документів та їх змісту, методу їх висвітлення та інтерпретації у мас-медіа. Політичний аналіз включає в себе систематичну оцінку реальності та політичної життєздатності альтернативних політик, що зазвичай мають форму політичних документів. Вивчення відповідних документів дає досліднику важливу інформацію про зовнішню політику держав та тенденції їх розвитку, про мотиви прийняття зовнішньополітичних рішень в тій чи іншій міжнародній ситуації.

Проте щодо вивчення актуальних проблем міжнародних відносин, даний метод має ряд недоліків. Оскільки частина документів може носити закритий характер, у зв'язку з державною таємницею, дослідник, оперуючи тільки відкритими джерелами та не володіючи усією інформацією щодо розгортання подій міжнародної 
ситуації, може зробити хибний висновок. Саме тому, якщо доступні документи не дають можливості адекватно оцінити наміри, цілі, передбачити можливі рішення і дії учасників зовнішньополітичного процесу, фахівці можуть застосовувати контент-аналіз.

Метод контент-аналізу застосовується для обробки значного за обсягом, несистематизованого текстового матеріалу, він особливо корисний у випадках, коли важливі для дослідження категорії, характеризувалися певними повтореннями у досліджуваних документах. В історії контент-аналізу першим прикладом застосування такого методу зазвичай вважають оцінку шведськими церковними діячами XVIII ст. збірника нових релігійних пісень та гімнів на предмет їх відповідності релігійним канонам. Це здійснювалося шляхом порівняння викладених у нових піснях релігійних ідей із трактуванням їх у вже існуючих офіційних релігійних текстах. Внаслідок цього їх визнали такими, що не відповідають релігійним догматам. Щоправда, це були радше форми порівняльного аналізу змісту текстів з метою їх цензурування, ніж контент-аналіз у його сучасному тлумаченні.

Становлення наукового контент-аналізу в його нинішньому вигляді відбулося тоді, коли засоби масової комунікації стали засобами масового впливу на громадську думку. Термін «контентаналіз» почали використовувати наприкінці XIX - на початку XX ст. американські журналісти Дж.Спід й Д.Уілкокс, а остаточно він закріпився у науковому обігу завдяки таким дослідникам у галузях журналістики, політології, соціології, політичної психології, як Б. Меттьюз, М.Уіллі, С. Кінгсбері, А. Кларк, Г. Харт, Дж. Вудворд і, безумовно, Г. Лассуелл.

Так, наприклад, при аналізі текстів звертається увага на найбільш вживані слова, які визначають основну ідею і концепцію документу, що дозволяє зробити висновок про його функціональну спрямованість.

При аналізі міжнародних відносин знаходить застосування і метод івент-аналізу (аналіз подій), заснований на спостереженні за динамікою подій, що відбуваються на міжнародній арені 3 метою виокремлення основних тенденцій розвитку політичної ситуації в досліджуваних країнах, регіонах і в світі в цілому. Згідно з даними досліджень, за допомогою івент-аналізу можна успішно вивчати міжнародні переговори. У цьому випадку в центрі уваги перебуває динаміка поведінки учасників переговорного процесу, інтенсивність висування пропозицій, динаміка взаємних поступок тощо.

Висновки. Отже, в статті розглянуто методологічні аспекти 
аналізу та прогнозування в системі міжнародних економічних відносин. Проаналізовано методи контент-аналізу та івент-аналізу. Перспективи подальших досліджень у даному напрямі полягають у пошуку результативних теоретико-практичних механізмів аналізу та прогнозування міжнародних економічних відносин за конкретними сферами їх застосування (наприклад пенсійна система, освіта, медицина), що забезпечить можливість, по-перше, органам державної влади більш правильно реагувати на новітні виклики, а, по-друге, сприятиме розробці альтернативних варіантів реформування стратегічних галузей політичної та соціальноекономічної систем.

1. Козик В. В. Міжнародні економічні відносини : навч. посіб. К. : Знання, 2006. 406 с. 2. Політична аналітика в системі публічного управління : навч. посіб. / авт. кол. С. О. Телешун, С. В. Сьомін, О. Р. Титаренко та ін. ; за заг. ред. С. О. Телешуна. К. : НАДУ, 2008. 284 с. 3. Філіпенко А. С. Міжнародні економічні відносини : підручник. К. : Либідь, 2008. 408 с. 4. Циганкова Т. М. Глобальна торгова система: розвиток інститутів, правил, інструментів СОТ : монографія. К. : КНЕУ, 2003. 660 с.

\section{REFERENCES:}

1. Kozyk V. V. Mizhnarodni ekonomichni vidnosyny : navch. posib. K. : Znannia, 2006. 406 s. 2. Politychna analityka $v$ systemi publichnoho upravlinnia : navch. posib. / avt. kol. S. O. Teleshun, S. V. Somin, O. R. Tytarenko ta in. ; za zah. red. S. O. Teleshuna. K. : NADU, 2008. 284 s. 3. Filipenko A. C. Mizhnarodni ekonomichni vidnosyny : pidruchnyk. K. : Lybid, 2008. 408 c. 4. Tsyhankova T. M. Hlobalna torhova systema: rozvytok instytutiv, pravyl, instrumentiv SOT : monohrafiia. K. : KNEU, 2003. $660 \mathrm{~s}$.

Harnaha O. M. [1; ORCID ID: 0000-0002-5236-7299], Candidate of Economics (Ph.D.), Associate Professor

${ }^{1}$ National University of Water and Environmental Engineering, Rivne

\section{ANALYSIS AND FORECASTING IN THE SYSTEM OF INTERNATIONAL ECONOMIC RELATIONS}

International economic relations of the world cannot develop effectively without their analysis and development of qualitative forecasts. It is noted that one of the main functions of management is the function of forecasting, which comes directly from the nature of the concept of management, as it must solve both current problems and future problems. In general, the forecast in science means a probable, scientifically sound judgment about the future. Political and socio-economic forecasting in the international arena are extremely closely linked, as the social system is 
interconnected with the political system, moreover, its development and structure depend on the processes of transformation or modernization of the political system. Thus, the development of effective and adequate international social forecasts is impossible without similar work in the international political sphere and vice versa.

The problem of determining forecasting methods in the system of international economic relations remains debatable. Thus, some researchers include expert methods, methods of extrapolation and modeling. Another group of scientists divides forecasting methods into general scientific and partial scientific. In our opinion, the most optimal is the selection of a general scientific group of forecasting methods, which consists of analysis, synthesis, extrapolation, interpolation, induction, deduction, analogy, hypothesis, experimentation, etc. Innovative methods that focus on collective thinking include brainstorming, expert surveys, testing, and the Delphi method.

A key factor in effective socio-economic forecasting in the international arena is the availability of highly professional specialists and institutions capable of developing and presenting forecasts.

Methods of content analysis and event analysis are analyzed. When using the method of content analysis, attention is paid to the most commonly used words that define the main idea and concept of the document, which allows us to conclude about its functional orientation. The method of event analysis is based on the observation of the dynamics of events in the international arena in order to determine the main trends in the political situation in individual countries. It is substantiated that the use of these methods of analysis and forecasting will allow to respond more adequately to the latest challenges, will contribute to the development of alternative options for reforming strategic areas of the political and socio-economic system.

Keywords: analysis; forecasting; international relations; planning; foreign policy forecasting.

Гарнага А. Н. [1; ORCID ID: 0000-0002-5236-7299], к.э.н., доцент

${ }^{1}$ Национальный университет водного хозяйства и природопользования, г. Ровно

АНАЛИЗ И ПРОГНОЗИРОВАНИЕ В СИСТЕМЕ МЕЖДУНАРОДНЫХ ЭКОНОМИЧЕСКИХ ОТНОШЕНИЙ

В статье рассмотрены методологические аспекты анализа и прогнозирования в системе международных экономических отношений. Отмечено, что чем выше и детальнее уровень разработки прогнозов и их 
Серія «Економічні науки»

Випуск 2(94) 2021 p.

качество, чем достовернее и эффективнее они, тем результативнее является планирование и управление международным экономическим развитием общества. Проанализированы методы контент-анализа и ивент-анализа.

Ключевые слова: анализ; прогнозирование; международные отношения; планирование; внешнеполитическое прогнозирование.

Отримано: 28 травня $2021 \mathrm{p.}$ Прорецензовано: 02 червня 2021 р. Прийнято до друку: 25 червня 2021 р. 